\title{
Immediate Effect of Sustained Stretching Exercises with Far Infrared on the Ankle Range of Motion and Muscle Tone in Patients with Stroke
}

\author{
Pong Sub Youn ${ }^{1}$, Shin Jun Park² \\ 'Department of Physical Therapy, Bundang Jesaeng General Hospital, Seongnam; ²Department of Physical Therapy, Gangdong University, Eumseong, \\ Korea
}

Purpose: The spasticity of stroke patients decreases the ankle range of motion and increases the gastrocnemius muscle tone. This study examined the effects of stretching exercise and far infrared irradiation on the ankle function in stroke patients with spasticity.

Methods: This study was conducted on 20 stroke patients admitted to Jesaeng General Hospital, who were divided into a study group (stretching exercise with far infrared) and control group (stretching exercise only). The dorsiflexion range of motion was measured using a smartphone and the medial gastrocnemius muscle tone and stiffness were measured using a Myoton pro.

Results: With the exception of the non-paretic gastrocnemius muscle tone in the control group, the medial gastrocnemius muscle tone and stiffness decreased significantly in both groups. In both groups, the dorsiflexion range of motion increased significantly. In addition, the experimental group had a significantly higher dorsiflexion range of motion than the control group. On the other hand, there was no significant difference between the two groups in terms of the medial gastrocnemius muscle tone and stiffness.

Conclusion: For stroke patients with spasticity, stretching exercises increased the ankle's range of motion and decreased the gastrocnemius muscle tone. The addition of heat therapy further increased the ankle's range of motion. On the other hand, as the sample size was small, future studies should include more subjects.

Keywords: Stroke, Stretching exercise, Far infrared, Heat therapy, Muscle tone, Ankle range of motion

\section{서 론}

뇌졸중 후 $80 \%$ 이상의 환자에서 반쪽 마비가 발생하고 그중 $60 \%$ 이 상 환자에서 다리 마비가 나타난다.' 뇌졸중 환자의 발목은 수동 토 크 증가, 반사 항진, ${ }^{2}$ 구축이 발생한다. 또한 뇌졸중 환자의 구축과 경 직(spasticity)은 발목관절 뺏뺏함을 일으키고 ${ }^{2}$ 경직(spasticity)이 높은 환자일수록 근 긴장도가 높아지며, ${ }^{4}$ 발목 관절의 경직(spasticity)으로 인한 움직임 결여는 비대칭적 체중이동, 자세 불안정성, 비정상적 보 행 패턴을 발생하게 된다.5, 장딴지 근 긴장도가 감소할수록 균형 능 력이 증진되므로 ${ }^{7}$ 뇌졸중 환자의 근 긴장도를 감소시켜 발목 관절의 경직(spasticity)을 줄이고 관절가동범위를 증진을 통해 기능 회복을 증진시키는 중재프로그램 개발이 필요하다.5.6

관절 및 근육의 움직임을 개선시킬 수 있는 중재 방법 중 하나인 열 치료는 $40^{\circ} \mathrm{C}$ 에서 $45^{\circ} \mathrm{C}$ 의 열이 골지힘줄기관의 억제효과를 증가
시키고 근 방추 이차 종말의 발화율은 낮추어 근 경련을 완화시키는 기전이 있다. 또한 열 치료에 의한 피부 온도 상승은 혈류 순환을 돕 고 조직의 점탄성을 변화시켜 근육의 이완과 관절의 뺏뺏함을 감소 시키기 때문에 움직임의 효율성을 증가시킬 수 있다. 본 연구의 열 치 료 방법은 적외선 치료로 3.0-100 $\mu \mathrm{m}$ 파장의 광선으로 파장이 길기 때문에 짧은 파장의 열 부하보다 표피 온도를 더욱 높일 수 있는 특징 을 가지고 있다.

원적외선의 생물학적 효과는 국소 부위에 혈액순환을 증가시켜 피부온도가 상승하고 상승한 피부 온도를 일정하게 유지시킨다. ${ }^{10}$ 상 승한 피부온도는 혈액순환을 통한 열 수송에 의해 경직을 감소시킨 다." 특히, 원적외선 치료는 굴곡이 있는 부위에 적용이 가능하고, 신 체 움직임 시 동시에 적용할 수 있는 이점이 있으므로, ${ }^{12}$ 뇌졸중 환자 의 운동과 결합하였을 때 원적외선 치료가 적합하다고 판단된다.

한편, 뻗침 운동은 짧아진 연부조직의 구조물을 늘여서 정상 관절
Received Jan 11, 2019 Revised Feb 18, 2019

Accepted Feb 28, 2019

Corresponding author Shin-Jun Park

E-mail3178310@naver.com
Copylight (C2019 The Korean Society of Physical Therapy

This is an Open Access article distribute under the terms of the Creative Commons Attribution Non-commercial License (Http:// creativecommons.org/license/by-nc/4.O.) which permits unrestricted non-commercial use, distribution, and reproduction in any medium, provided the original work is properly cited. 
가동범위를 유지 및 회복시키는 운동 치료의 한 방법이다.13 수축성 조직은 빠른 뻗침의 경우 근 방추를 흥분시켜서 근 긴장을 증가시킬 수 있는 반면 느린 뻗침 운동은 골지힘줄기관을 자극하여 근육의 긴 장을 억제한다. ${ }^{13}$ 뇌졸중 환자에게 적용한 뻗침 운동은 근육의 점탄 성을 변화시켜 경직(spasticity) 감소에 효과가 있다. ${ }^{14}$ 선행연구에서 정 상인에게 적용한 15 분의 지속적인 뼏침 운동은 관절가동범위 증가 가 가능하고, ${ }^{15}$ 경직(spasticity)이 있는 아동에서는 10 초간 뻗침보다 30 초간의 뻗침이 경직(spasticity)에 감소를 보였다. ${ }^{16}$

뼏침 운동은 단일 적용한 것보다 심부 열 치료인 초음파 치료, ${ }^{17}$ 맥 동단파치료를 18 결합했을 때 더욱 관절가동범위 개선 효과가 더욱 뛰 어나다. 더하여 표재열 치료인 온습포를 적용하였을 때에도 단일 뻗 침 운동보다 확장능(extensibility)에 더욱 효과적이었다.16 하지만 지금 까지 선행연구들은 건강인이나 경직(spasticity)이 있는 아동에게 뻗 침 운동과 열 치료를 적용한 연구였고 측정 방법에 있어서도 $\mathrm{EMG}$ 나, ${ }^{16}$ 관절가동범위만 확인한 연구였다.1718

이에 본 연구에서는 원적외선 치료와 뻗침 운동을 실시했을 때 뇌 졸중 환자의 장딴지 근 긴장도 및 발목 관절가동범위에 미치는 영향 을 확인한 후 경직(spasticity)을 감소시킬 수 있는 새로운 중재 방법을 제안하고자 이 연구를 진행하였다.

\section{연구 방법}

\section{1. 연구대상}

본 연구는 경기도에 소재한 J종합병원에 뇌졸중을 진단받고 6개월 이상 된 반신마비 환자 20 명을 대상으로 연구가 진행되었다. 모든 연 구대상자는 본 연구의 목적과 취지를 충분히 설명받았고 자발적 동 의를 하였다. 대상자 선정 조건은 한국형 간이정신상태검사에서 24 점 이상인 자, 다리에 정형외과적 질환이 없는 자, 피부질환이 없는 자, 온도 감각에 이상이 없는 자를 선정하였다.

온도 감각 검사는 $18^{\circ} \mathrm{C}, 37^{\circ} \mathrm{C}, 42^{\circ} \mathrm{C}$ 온도에 물을 함유한 시험관을 비 마비측과 마비측 종아리에 3 초 이상 두어 차갑거나, 따뜻하거나, 뜨겁다고 느껴지는 온도 감각을 확인하였다. 연구 과정 중 체온 이상 증세(고체온증 및 저체온증)를 보이거나 두통 및 어지러움을 호소하 는 자가 발생했을 시 연구 참여를 제한하려 했으나 특이 사항은 없었 다. 20 명의 대상자는 컴퓨터 난수 프로그램을 이용하여 뼏침 운동과 원적외선 동시 적용군 (연구군, $\mathrm{n}=10$ ), 뻗침 운동군 (대조군, $\mathrm{n}=10$ )으 로 무작위 배치하였다. 모든 측정은 중재 전과 중재 후 실시하였다.

\section{2. 실험방법}

\section{1) 측정 절차}

본 연구의 모든 측정은 임상 경력 10 년차 이상의 물리치료사가 측정
하였고 각 평가 시 낙상 방지 및 안전을 위해 한 명의 연구보조자가 배 치되었다. 본 연구에서는 뻗침 운동과 적외선의 즉각적인 효과를 확 인하고자 중재 전 사전 측정을 실시하였고 중재가 끝나고 10 분 이내 에사후 측정을 실시하였다.

(1) 발등 굽힘 관절가동범위 측정(measurement of dorsiflexion range of motion)

뇌졸중 환자의 마비측 발등 굽힘 관절가동범위를 측정하기 위해 스 마트폰(아이폰 7 plus, Al784, Apple, USA)에 내장되어 기본 애플리케 이션 나침반(수직계)을 이용하였다. 스마트폰의 수직계를 이용하여 발목의 발등 굽힘 측정은 0.08 의 높은 신뢰도를 보였다. ${ }^{22}$ 측정방법은 비 마비측 다리를 앞쪽으로 내밀고 무릎을 약간 구부린 상태에서 벽 을 마주보고 서도록 하였다. 마비측 다리는 곧게 피고 발뒤꿈치를 발 바닥에 닿도록 하였다. 양쪽 발뒤꿈치를 지면에 붙이고 엉덩이가 벽 쪽을 향하도록 유도하였다. 안전을 위해 벽에 손을 짚도록 하였고 마 비측 다리와 골반이 한쪽으로 기울지 않도록 한 명의 보조자가 조절 하였다. 측정은 스마트폰 밑면을 아킬레스 힘줄 $1 \mathrm{~cm}$ 위쪽 부위에 놓 고 지면과 스마트폰의 밑면이 이루는 기울기 각도(slop angle)를 측정 하였다.

(2) 근 긴장도 측정(muscle tone)

뇌졸중 환자의 근 긴장도를 측정하기 위해 근 긴장도 측정기(Myotone ${ }^{\circledR} \mathrm{PRO}$, Estonia)를 사용하였다. 이 장비는 뇌졸중 환자의 근 긴장 도 측정에 객관성과 타당성이 입증되었다. ${ }^{21}$

불필요한 근 긴장을 제거하기 위해 측정 시 치료실 온도는 $25^{\circ} \mathrm{C}$ 를 유지하고 대상자는 안정 상태로 5 분 휴식한 후 엎드린 자세를 취하고 측정하였다. 측정 근육은 안쪽 장딴지근을 선택하였고, ${ }^{7}$ 근육의 힘살 에 수성 보드 마커로 표시한 뒤 장비를 근육과 수직으로 세워 공진 동 5 회로 세팅하여 탐침봉이 표식점을 벗어나지 않게 두 손으로 받치 고 2회에 걸쳐 측정하여 평균값을 데이터값으로 사용하였다.

\section{2) 중재 방법}

모든 연구대상자는 스탠딩 테이블을 이용하여 고정형 경사판(wedge board) 위에 서서 15 분간 지속적인 뻗침 운동을 실시하였다. 경사판 의 각도는 $15^{\circ}-40^{\circ}$ 까지 6 가지 각도가 준비되었고 환자의 발목 관절에 맞추어 통증이 일어나지 않는 범위에서 각도를 각각 설정하여 적용 하였다. 연구군과 대조군은 스탠딩 테이블을 이용하여 기립 자세를 유지하도록 하였고 고정형 경사판 위에 올라설 수 있도록 하였다. 가 급적 바른 기립 자세로 뻗침 운동을 하기 위해 테이블과 신체 사이 압 박의 불편함을 호소하지 않은 상태에서 기립하도록 조절 장치로 고 정하였다. 15 분간의 지루함을 피하고자 정면에 모니터를 설치하고 
$\mathrm{TV}$ 를 시청할 수 있도록 하였으며 근육의 손상을 막기 위해 뻗침 운 동 중 불편함을 호소하면 중간에 각도를 조정하도록 하였다. 연구군 은 원적외선(Cerapia 310, NIHON MEDIX, Japan)을 동시에 적용하였 다. 원적외선 조사기는 기기 자체의 중심 파장이 6-10 $\mu \mathrm{s}$ 이고, 크기는 $150 \times 300 \mathrm{~mm}$, 움직임의 범위는 $-90^{\circ}$ 에서 $+90^{\circ}$, 열이 조사되는 판은 세 라믹 발열체로 되어있다. 연구군은 경사판 위에 선 자세를 취하고 적 외선 조사기는 대상자의 뒤쪽에 위치한 후 마비측 종아리에 수직 방 향으로 적외선을 조사하였다. 적외선 조사기와 피부와의 거리는 25 $\mathrm{cm}$, 조사 시간은 15 분으로 하였다. 온도는 $45^{\circ} \mathrm{C}$ 이내로 대상자가 따 뜻하다고 느낄 정도로 하였고, 뜨겁게 느껴지는 대상자의 한에서 조 사기의 거리를 늘려 적용하도록 하였다(Figure 1).

\section{3. 자료 분석}

모든 자료 분석은 SPSS 20.0 을 이용하여 통계 처리하였다. 모든 대상 자의 일반적 특성은 카이제곱(Gender, Paretic side) 독립 표본 t-검정 (age, height, onset, MMSE), 맨휘트니 U-검정(weight, MAS)을 이용하여 동질성을 확인하였고 평균과 표준편차는 기술 통계를 이용하였다. 초기 값에 대한 샤피로윌크 검정에서 유의한 차이가 나타나지 않을 경우(dorsiflexion range of motion, paretic muscle tone) 연구군 내 전후

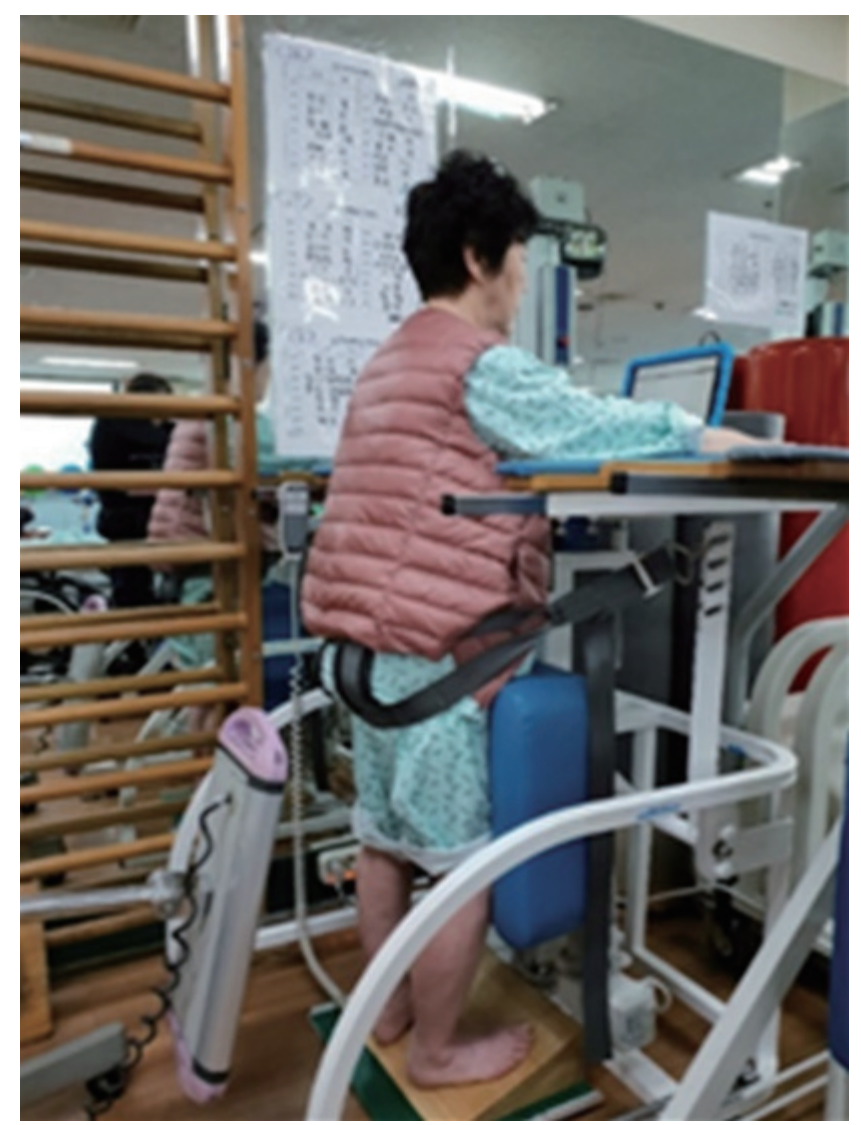

Figure 1. Sustained stretching exercise with far infrared.
변화차이는 대응표본 $\mathrm{t}$-검정으로, 유의한 차이가 나타날 경우(paretic stiffness, non paretic muscle tone, non paretic stiffness) 윌콕슨 부호 순 위 검정을 이용하였다. 마찬가지로 샤피로윌크 검정에서 유의한차이 가 나타나지 않은 경우 연구군 간 차이 값 비교는 독립 표본 t-검정(평 균과 표준편차)으로, 유의한 차이가 나타날 경우 맨휘트니 U-검정 (평균 순위)을 이용하였다. 본 연구의 통계학적 유의 수준은 $\alpha=0.05$ 로 설정하였다.

\section{결 과}

\section{1. 연구대상자의 일반적 특성}

연구대상자의 일반적 특성은 Table 1과 같다. 대조군과 연구군 모두 성별, 마비측, 나이, 키, 몸무게, 발병일, MAS, MMSE에 유의한 차이가 없었으므로 두 군 간 동질함을 확인할 수 있었다(Table 1).

\section{2. 중재 전후 발등 굽힘 관절가동범위의 변화}

대조군과 연구군 모두 발등 굽힘근 발목관절가동범위에 유의한 증가 가 있었다 $(\mathrm{p}<0.05)$. 하지만 두 군 간 변화량 차이에서는 연구군이 대

Table 1. Subject characteristics

\begin{tabular}{lccc}
\hline Categories & $\begin{array}{c}\text { Control group } \\
(n=10)\end{array}$ & $\begin{array}{c}\text { Experimental } \\
\text { group }(n=10)\end{array}$ & $p$ \\
\hline Gender & & & 0.371 \\
$\quad$ Male & 4 & 6 & \\
$\quad$ Female & 6 & 4 & 0.653 \\
Paretic side & 4 & 5 & \\
Right & 6 & 5 & \\
Left & $59.00 \pm 14.85$ & $57.30 \pm 13.62$ & 0.793 \\
Age (yr) & $166.30 \pm 8.26$ & $165.10 \pm 6.89$ & 0.728 \\
Height (cm) & $58.20 \pm 6.50$ & $61.60 \pm 4.58$ & 0.183 \\
Weight (kg) & $16.90 \pm 9.86$ & $20.40 \pm 10.96$ & 0.462 \\
Onset (month) & $1.40 \pm 0.52$ & $1.60 \pm 0.52$ & 0.383 \\
MAS (point) & $27.70 \pm 1.63$ & $26.70 \pm 1.89$ & 0.222 \\
MMSE (point) & & &
\end{tabular}

Values are shown as the mean $\pm S D,{ }^{*} p<0.05$.

Table 2. Variation of dorsiflexion range of motion within and between group

\begin{tabular}{lccc}
\hline Variable & $\begin{array}{c}\text { Control group } \\
(n=10)\end{array}$ & $\begin{array}{c}\text { Experimental } \\
\text { group }(n=10)\end{array}$ & $p$ \\
\hline Dorsiflexion range of motion & & & \\
$\quad$ Before & $16.90 \pm 1.72$ & $17.10 \pm 1.60$ & \\
After & $18.20 \pm 2.10$ & $20.10 \pm 2.02$ & \\
Change & $1.30 \pm 0.82$ & $3.00 \pm 1.15$ & $0.001^{*}$ \\
$p$ & $0.001^{*}$ & $0.000^{*}$ & \\
\hline
\end{tabular}

Values are shown as the mean $\pm S D,{ }^{*} p<0.05$. 
Table 3. Variation of gastrocnemius muscle tone and stiffness within and between group

\begin{tabular}{|c|c|c|c|}
\hline Variable & Control group $(n=10)$ & Experimental group $(n=10)$ & $\mathrm{p}$ \\
\hline \multicolumn{4}{|l|}{ Paretic medial gastrocnemius muscle tone } \\
\hline Before & $16.85 \pm 0.94$ & $16.80 \pm 1.23$ & \\
\hline After & $16.07 \pm 0.70$ & $15.80 \pm 1.23$ & \\
\hline Change & $-0.78 \pm 0.42$ & $-1.00 \pm 0.00$ & 0.112 \\
\hline $\mathrm{p}$ & $0.000^{*}$ & $0.000^{*}$ & \\
\hline \multicolumn{4}{|l|}{ Paretic medial gastrocnemius muscle stiffness } \\
\hline Before & $290.90 \pm 38.82$ & $303.80 \pm 43.60$ & \\
\hline After & $276.90 \pm 34.82$ & $286.50 \pm 40.50$ & \\
\hline Change & 12.20 & 8.80 & 0.196 \\
\hline $\mathrm{p}$ & $0.005^{*}$ & $0.005^{*}$ & \\
\hline \multicolumn{4}{|l|}{ Non-paretic medial gastrocnemius muscle tone } \\
\hline Before & $17.20 \pm 0.78$ & $17.00 \pm 1.15$ & \\
\hline After & $16.84 \pm 0.94$ & $16.40 \pm 1.25$ & \\
\hline Change & 11.80 & 9.20 & 0.268 \\
\hline $\mathrm{p}$ & 0.059 & $0.014^{*}$ & \\
\hline Non-paretic medial gastrocnemius muscle stiffness & $301.80 \pm 48.20$ & $315.70 \pm 44.98$ & \\
\hline Before & $295.60 \pm 47.06$ & $305.90 \pm 41.98$ & \\
\hline After & 12.20 & 8.80 & 0.194 \\
\hline Change & $0.007^{*}$ & $0.008^{*}$ & \\
\hline $\mathrm{p}$ & & & \\
\hline
\end{tabular}

Values are shown as the mean \pm SD and mean rank, ${ }^{*} p<0.05$.

조군 보다 유의한 차이를 보였다 $(\mathrm{p}<0.05)($ Table 2).

\section{3. 중재 전후 안쪽 장딴지 근 긴장도 및 뻣벗함 변화}

대조군에서 비 마비측 안쪽 장딴지 근 긴장도를 제외하고 $(\mathrm{p}>0.05)$, 연구군과 대조군 모두 안쪽장딴지 근 긴장도 및 뻣뻣함에 유의한 감 소가 있었다 $(\mathrm{p}<0.05)$. 하지만 두 군 간 변화량 차이에서는 연구군과 대조군 간 유의한 차이가 없었다( $>>0.05)$ (Table 3).

\section{고 찰}

연구결과 뻗침 운동과 원적외선을 적용한 연구군과 뻗침 운동만 적 용한 대조군 모두 마비측과 비 마비측 장딴지 근 긴장도 및 뺏뻣함이 감소하였고 대조군에서 비 마비측 장딴지 근 긴장도를 제외하고 모 두 유의하게 감소하였다. 발등 굽힘 관절가동범위에서는 두 군 모두 유의한 증가가 있었고, 연구군은 대조군보다 발목관절가동범위가 유의하게 증가하였다. 하지만 장딴지 근 긴장도 및 뻣뻣함에는 두 군 간 유의한 차이가 없었다.

열 치료는 일반적으로 건열과 습열로 나뉘고 심부열치료와 표재열 치료로 구분된다. 열 치료의 열 발생 원리는 각기 다르므로 금기 사항 과 적응 사항은 분명한 차이를 두지만 치료 효과는 큰 차이가 없고, 거의 유사하므로 열 치료가 필요한 대상자라면 대상자의 특성, 선호
도, 경제성, 간편성에 따라 적용되어야 할 것이다. ${ }^{23}$ 선행연구에서 표 재열 치료인 적외선 치료와 심부 열 치료인 초음파 치료를 뇌졸중 환 자의 장딴지근에 적용한 후 효과를 비교하였다. 그 결과 두 방법 모두 관절의 가동범위 회복에 유사한 효과를 보였고 방법 간에 차이가 없 었다. ${ }^{24}$ 본 연구에서 선택한 열 치료는 원적외선 치료로 긴 파장의 열 부하가 짧은 파장의 열 부하보다 길기 때문에 표피 온도를 더욱 높일 수 있는 이점이 있어서 원적외선을 적용하였다. 원적외선 형태의 온 엄법(hot compress)은 뇌졸중 환자의 피부 전기 전도도와 피부 온도 를 유의하게 증가시켰고, ${ }^{25}$ 기능적 전기 자극과 동시에 적용한 원적외 선 치료는 뇌성마비 아동의 경직(spasticity) 감소에 효과를 보였다.14 원위 적외선 적용 후 전기 저항과 통증, 온도에 미치는 영향을 확인한 것이 대부분이었다.25 열 치료의 경우 단일 적용하는 것보다 열 치료 와 운동치료를 결합하는 것이 관절가동범위 회복에 더욱 효과적이 기 때문에, ${ }^{26}$ 본 연구에서는 두 중재 방법을 결합하였다.

건강인의 장딴지근 근육힘줄접합부에 $3 \mathrm{MHz}$ 로 7분간 초음파 적 용한 다음 실시한 뻗침 운동은 단일 뻗침 운동보다 최대 발등 굽힘 가동범위가 더욱 증가하였고, ${ }^{17} 27.12 \mathrm{MHz}$ 로 맥동 단파 투열 치료기 드럼 전극을 근육 힘줄 접합부에 두어 고주파 치료 20 분 적용과 도르 래 무게를 이용하여 일정한 부하를 주는 10 분간의 장딴지 근 뻗침 운 동은 장딴지 근 뻗침 운동 10 분 단일적용보다 발등 굽힘 관절가동범 위 증가에 더욱 효과적인 방법이었다. ${ }^{18}$ 또한 경직(spasticity)이나 과 긴 
장이 있는 아동의 넙다리뒤근(hamstring)에 적용한 뻗침 운동은 10 초적용보다 30 초적용이 넙다리뒤근 $\mathrm{rmsEMG}$ 신호가 더욱 감소하였 고, 20 분간 온습포를 적용한 후 뻗침 운동하는 것이 뻗침 운동 단일 적용보다 더욱 넙다리뒤근 확장능을 향상시킬 수 있었다. ${ }^{16}$ 그러므로 본 연구에서 적용한 원적외선 치료가 피부 온도를 상승시키고 혈액 순환이 촉진되어 근 방추 반응이 감소 및 근육 이완이 가능하기 때 문에, ${ }^{8,11}$ 지속적인 뻗침에 대한 $\mathrm{GTO}$ 의 활성과 열 치료에 의한 근 방추 민감도 감소의 효과가 더해져 뇌졸중 환자의 발목관절 유연성을 개 선시키고 그 결과 뻗침 운동 단일 적용 시보다 열 치료 동시 적용이 발목관절 가동 범위에 더욱 효과적인 것으로 사료된다.

이처럼 경직(spasticity)이 있는 환자에게 중재 되는 뻗침 운동은 경 직(spasticity) 감소와 관절가동범위 개선이 가능한 중재 방법이고, ${ }^{14}$ 열 치료와 결합 시 더욱 관절가동범위에 더욱 효과적인 물리치료의 방법인 것을 알 수 있었다. ${ }^{16}$ 현재 열 치료와 뻗침 운동을 적용한 선행 연구에서는 열 치료와 뺃침 운동을 동시에 적용하기보다는 열 치료 후 뻔침 운동에 초점이 맞춰지고 있는 실정이다. 본 연구에서는 시간 적 차이를 통제시키기 위해서 적외선 치료와 뻗침 운동을 동시에 실 시하였고 그 결과 연구군이 대조군보다 발등 굽힘 관절가동범위에 보다 유의하게 증가되는 것을 확인할 수 있었다.

하지만 연구군과 대조군의 근긴장도와 뺏뻣함의 변화를 비교하였 을 때에는 유의한 차이가 없었다. 이러한 이유는 뻗침 운동만으로 근 육의 긴장도를 충분히 감소시킬 수 있었기 때문에 두 군간차이가 나 타나지 않은 것으로 사료된다. 초음파나 적외선 치료는 뇌졸중 환자 의 발목 관절가동범위를 증가시킬 수 있었던 반면 경직(spasticity)을 감소시킬 수 없었다는 선행연구 결과와, ${ }^{24}$ 경직형뇌성마비 아동에게 적용한 연구에서 ${ }^{16}$ 온습포와 뻗침 운동은 뻗침 운동 단일 적용보다 넙다리뒤근 확장능력(extensibility)에 더 큰 차이가 있었고 넙다리뒤 근 $\mathrm{EMG}$ 은 차이가 없었으며 뻗침 운동 단일 적용이 넙다리뒤근 $\mathrm{EMG}$ 를 유의하게 감소시킨 선행연구 결과는 본 연구 결과를 지지해 준다.

바로 선 자세에서 장딴지근 뻗침 운동은 증가된 발등 굽힘을 의미 하는 근육힘줄접합부 변위가 초음파상에서 확인되었다. ${ }^{28}$ 뇌졸중 환 자의 발목에 적용한 에비엔즈-함베르크 뻗침 운동은 발등 굽힘 관절 가동범위를 증가시켰고, ${ }^{29}$ 본 연구와 비슷한 방법으로 뇌졸중 환자에 게 경사침대를 이용하여 발목 관절에 지속적인 뻗침 운동은 발등 굽 힘 가동범위 증가와 앞정강근 $\mathrm{F} / \mathrm{M}$ 비(ratio) 증가, 종아리 세갈래근 운 동신경흥분성을 의미하는 $\mathrm{H} / \mathrm{M}$ 비(ratio)에 유의한 감소를 보였다. ${ }^{16}$

뇌졸중 환자의 경우, 경직(spasticity)으로 인한 근 긴장 변화를 관리 하지 못하여 관절 구축이 나타날 수 있기 때문에 ${ }^{17}$ 관절가동범위뿐만 아니라 근육의 기계적 특성도 확인해야한다. 본 연구에서 확인하고자 하는 근육의 기능적 상태는 근 긴장도 검사기로 측정하였다.

뇌졸중 환자의 장딴지근에 뻗침 운동을 적용한 후 근 긴장도를 확
인한 선행연구가 없어 직접적인 비교는 어렵지만 경직(spasticity)이 있 는 환자일수록 근 긴장도가 높았고, ${ }^{20}$ 경직(spasticity)이 있는 뇌졸중 환자에게 장딴지근에 경피신경전기자극과 기능적전기자극을 적용 은 대상자의 장딴지근 긴장도 및 뻣뻣함에 감소를 가져다 주었다.7 따 라서 본 연구에서 나타난 근 긴장도 감소와 발등굽힘 증가는 뻗침운 동과 원적외선 적용에 따른 조직의 길이 변화가 점탄성 성질을 변화 시켜 나타난 결과일 수 있지만 뻗침에 의해 신경변화가 유도되어 운 동신경저장소의 구심성 입력을 감소시킴으로써 긴장 반사 활동의 감 소로 인해 나타난 것일 수도 있다. ${ }^{30}$ 더하여 대조군에서 비 마비측 장 딴지근 긴장도에 유의한 차이가 없었는데 유의 수준이 0.059 인 것과 대상자가 정규분포하지 않기 때문에 비모수 검정을 확인한 것으로 보았을 때 대상자 수가 적었기 때문에 나타났던 결과로 사료된다.

본 연구를 통해 뻗침 운동만으로 뇌졸중 환자의 경직근인 장딴지 근에 근 긴장도 및 뻣뻣함 감소와 관절가동범위 증진이 가능하다는 것을 알 수 있었고 적외선을 더한다면 관절가동범위에 더욱 효과적 인 것을 알 수 있었다. 하지만 발목 기능의 회복을 위해 뇌졸중 환자 를 대상으로 열 치료 효과와 뻗침 운동을 결합한 선행연구의 부족으 로 다양한 연구와 비교하지 못하였고, 정적인 상태에서 근 긴장도 수 준이 속도에 변화하는 경직(spasticity)을 직접적으로 평가했다고 보 기는 어렵다. 그럼에도 불구하고 본 연구를 통해 뻗침 운동을 방해하 지 않고 원적외선을 동시에 적용하여 발목 관절가동범위 증가 및 근 긴장도 감소를 검증한 점과 비마비측 긴장도 및 뻣뻣함도 감소를 확 인했다는 점에서 임상적 의의가 있다. 이후 지속적인 연구를 통해 뻗 침 운동과 원적외선 결합 후 다양한 평가에 관한 다각적이고 과학적 인 검증이 필요하겠다.

\section{REFERENCES}

1. Rathore SS, Hinn AR, Cooper LS et al. Characterization of incident stroke signs and symptoms findings from the atherosclerosis risk in communities study. Stroke. 2002;33(11):2718-21.

2. Lorentzen J, Grey MJ, Crone C et al. Distinguishing active from passive components of ankle plantar flexor stiffness in stroke, spinal cord injury and multiple sclerosis. Clin Neurophysiol. 2010;121(11):1939-51.

3. Vattanasilp W, Ada L, Crosbie J. Contribution of thixotropy, spasticity, and contracture to ankle stiffness after stroke. J Neurol Neurosurg Psychiatry. 2000;69(1):34-9.

4. Bae SJ, Lee JI, Kim KY. Usefulness of myotonometer for measurement of tissue compliance on medialis gastrocnemius in patients with stroke. JKAIS. 2012;13(3):1129-37.

5. de Haart M, Geurts AC, Huidekoper SC et al. Recovery of standing balance in postacute stroke patients: a rehabilitation cohort study. Arch Phys Med Rehabil. 2004;85(6):886-95.

6. Lin PY, Yang YR, Cheng SJ et al. The relation between ankle impairments and gait velocity and symmetry in people with stroke. Arch Phys Med 
Rehabil. 2006;87(4):562-8.

7. Park SJ, Cho KH, Cho YH. Effect of exercise with functional electrical stimulation and transcutaneous electrical nerve stimulation on muscle tone, stiffness of calf muscle, and balance ability in patients with stroke. J Korean Soc Phys Med. 2017;12(2):43-52.

8. Kitchen SS, Partridge CJ. Infrared therapy. Physiotherapy. 1991;77(4): 249-54.

9. Vatansever F, Hamblin MR. Far infrared radiation (FIR): its biological effects and medical applications. Photonics Lasers Med. 2012:1(4);255-66.

10. Yu SY, Chiu JH, Yang SD et al. Biological effect of far-infrared therapy on increasing skin microcirculation in rats. Photodermatology, Photoimmunology \& Photomedicine. 2006;22(2);78-86.

11. Matsumoto S, Kawahira K, Etoh S et al. Short-term effects of thermotherapy for spasticity on tibial nerve f-waves in post-stroke patients. International Journal of Biometeorology. 2006;50(4):243-50.

12. Kim YJ, Oh JL, Kim JY et al. The effect of functional electrical stimulation and far infrared on the ankle plantar flexor spasticity in cerebral palsy. J Kor Phys Ther. 2002;14(2):19-27.

13. Kisner C, Colby LA, Borstad J. Therapeutic exercise: foundations and techniques. Philadelphia, Fa Davis. 2017

14. Tsai KH, Yeh CY, Chang HY et al. Effects of a single session of prolonged muscle stretch on spastic muscle of stroke patients. Proc Natl Sci Counc Repub China B. 2001;25(2):76-81.

15. Yuk GC. The acute effects of 15 minutes plantar flexor static stretch in quite stance. J Korean Soc Phys Med. 2012;7(2)191-7.

16. Lee GP, Ng GY. Effects of stretching and heat treatment on hamstring extensibility in children with severe mental retardation and hypertonia. Clin Rehabil. 2008;22(9):771-9.

17. Draper DO, Anderson C, Schulthies SS et al. Immediate and residual changes in dorsiflexion range of motion using an ultrasound heat and stretch routine. J Athl Train. 1998;33(2):141-4.

18. Peres SE, Draper DO, Knight KL et al. Pulsed shortwave diathermy and prolonged long-duration stretching increase dorsiflexion range of motion more than identical stretching without diathermy. J Athl Train. 2002;37(1):43-50.
19. Gracies JM. Pathophysiology of spastic paresis. I: paresis and soft tissue changes. Muscle Nerve. 2005;31(5):535-51.

20. Fröhlich-Zwahlen AK, Casartelli NC, Item-Glatthorn JF et al. Validity of resting myotonometric assessment of lower extremity muscles in chronic stroke patients with limited hypertonia: a preliminary study. J Electromyogr Kinesiol. 2014;24(5):762-9.

21. Chuang LL, Wu CY, Lin KC. Reliability, validity, and responsiveness of myotonometric measurement of muscle tone, elasticity, and stiffness in patients with stroke. Arch Phys Med Rehabil. 2012;93(3):532-40.

22. Williams CM, Caserta AJ, Haines TP. The tilt meter app is a novel and accurate measurement tool for the weight bearing lunge test. J Sci Med Sport. 2013;16(5):392-395.

23. Kim JH. Rehabilitation of arthrits. J Muscle Jt Health. 1994;1(1):127-32.

24. Nakhostin AN, Naghdi S, Hasson S et al. Efficacy of therapeutic ultrasound and infrared in the management of muscle spasticity. Brain Inj. 2009;23(7-8):632-8.

25. Lin CC, Chiang YS, Lung CC. Effect of infrared-C radiation on skin temperature, electrodermal conductance and pain in hemiparetic stroke patients. Int J Radiat Biol. 2015;91(1):42-53.

26. Nakano J, Yamabayashi C, Scott A et al. The effect of heat applied with stretch to increase range of motion: a systematic review. Phys Ther Sport. 2012;13(3):180-8.

27. van der Salm A, Veltink PH, IJzerman MJ et al. Comparison of electric stimulation methods for reduction of triceps surae spasticity in spinal cord injury. Arch Phys Med Rehabil. 2006;87(2):222-8.

28. Jung DY, Koh EK, Kwon OY et al. Effect of medial arch support on displacement of the myotendinous junction of the gastrocnemius during standing wall stretching. J Orthop Sports Phys Ther. 2009;39(12):86774.

29. Park SJ, Cho KH, Kim SH. The Effects of Kaltenborn Orthopedic Manual Therapy with Evjenth-Hamberg stretching on range of motion of ankle joint and balance ability in patients with chronic stroke. J Korean Soc Phys Med. 2018;13(2):43-51.

30. Guissard N, Duchateau J. Neural aspects of muscle stretching. Exerc Sport Sci Rev. 2006;34(4):154-8. 